\title{
Case-resolving capacity of dental care of the Unified Health System: the perception of users in a city in the state of São Paulo, Brazil
}

\author{
Resolutividade do serviço odontológico no Sistema Único \\ de Saúde: a percepção de usuários de um município paulista, Brasil
}

\author{
Arinilson Moreira Chaves Lima ${ }^{1}$ \\ Cléa Adas Saliba Garbin ${ }^{1}$ \\ José Eduardo Corrente ${ }^{2}$ \\ Nemre Adas Saliba ${ }^{1}$ \\ Suzely Adas Saliba Moimaz ${ }^{1}$
}

${ }^{1}$ Departamento de Odontologia Infantil e Social, Faculdade de Odontologia de Araçatuba, Universidade Estadual Paulista (Unesp). R. José Bonifácio 1193, Vila Mendonça. 16015-050 Araçatuba SP Brasil. arinilsonchaves@ hotmail.com

${ }^{2}$ Departamento de Bioestatística, Instituto de Biociências de Botucatu,

Unesp. Botucatu SP Brasil.
Abstract The aim of this study was to learn about the users' perceptions concerning the case-resolving capacity of dental care in the Unified Health System and to analyze the associations between solving capacity and both sociodemograph$i c$ characteristics and access to the service. This was a cross-sectional study with a quantitative approach, in which 461 users responded to individual interviews. The outcome variable was the case-resolving capacity of dental care, obtained through the question: "In your opinion, is the dentist of this health center managing to solve all your oral health problems (Yes/No)". Independent variables were grouped into the following: sociodemographic and related to the access to the service. Most participants reported that their oral health problems were being solved. By using the Poisson regression, the lack of case-resolving capacity was found to be associated to the patients' not considering the dental surgeon's working hours convenient; to the long time they had to wait to get an appointment in the health center; and to the long time they had to wait in the waiting room. The results showed the positive view that users have about the case-resolving capacity of public dental care, and the relationship between access to the service and the said solving capacity.

Key words Dental care, Effectiveness, Unified Health System, Health services accessibility
Resumo O objetivo neste estudo foi conhecer a percepção do usuário sobre a resolutividade do serviço odontológico no Sistema Único de Saúde, $e$ analisar as associações entre resolutividade e características sociodemográficas e de acesso ao serviço. Tratou-se de uma pesquisa transversal com abordagem quantitativa, na qual 461 usuários responderam a entrevistas individuais. A variável desfecho foi a resolutividade do serviço odontológico, obtida através da seguinte pergunta: " $\mathrm{Em}$ sua opinião, o dentista desta unidade de saúde está conseguindo resolver todos os seus problemas de saúde bucal? (sim/não)". As variáveis independentes foram agrupadas em: sociodemográficas, e de acesso ao serviço. A maioria dos participantes relatou que seus problemas de saúde bucal estavam sendo resolvidos. Por meio da regressão de Poisson, observou-se que a falta de resolutividade esteve associada a não considerar o horário de trabalho do cirurgião-dentista conveniente; à grande demora para conseguir realizar o agendamento para a unidade de saúde; e ao tempo na sala de espera ser muito demorado. Os resultados revelaram a percepção positiva que o usuário teve sobre a resolutividade do serviço público odontológico, e a relação existente entre o acesso ao serviço e a capacidade resolutiva referida.

Palavras-chave Assistência odontológica, Efetividade, Sistema Único de Saúde, Acesso aos serviços de saúde 


\section{Introduction}

Brazil is a federative republic where more than 190 million people live ${ }^{1}$, spread out over 5,570 municipalities, totaling an area of $8,515,767$ square kilometers ${ }^{2}$. Such a continental dimension and the existing regional differences (geographical, cultural, social, and economic) make offering health care services to such an enormous population a constant challenge.

The current Brazilian health model, the Unified Health System (Sistema Unico de Saúde - SUS), is based on the premise that health is a right of every citizen and a duty of the State, and the purpose of which is to provide preventive and healing care, by means of a decentralized management, and with the participation of the community ${ }^{3}$.

In 2004, as the result of a long process of institutionalizing dental care in the Brazilian health system, the National Oral Health Policy (Politica Nacional de Saúde Bucal - PNSB) was created the so-called "Brazil Smiling" - which involved introducing more Oral Health Teams (Equipes de Saúde Bucal - ESBs) in the Family Health Strategy (Estratégia Saúde da Família - ESF); and setting up Dental Specialty Centers (Centros de Especialidades Odontológicas - CEOs) ${ }^{4}$.

Although data from December 2015 indicate the existence of 24,467 ESBs in 5,014 Brazilian municipalities $^{5}$ and 1,022 CEOs throughout the country $^{6}$, the most recent National Health Survey, conducted in 2013, showed that almost one decade after the "Brazil Smiling" Program was introduced, as much as $74.3 \%$ of dental care in Brazil still takes place in private clinics or dental practices ${ }^{7}$; raising doubts about the case-resolving capacity of the oral health service of the SUS.

Case-resolving capacity is regarded as the satisfactory outcome that a health service provides to users when they seek such a service, be it the cure of illnesses, the relief of suffering, or the promotion and maintenance of health ${ }^{8}$. The purpose of a user in seeking dental care of a public oral health service is to improve their health condition, solve problems, and correct dysfunctions 9 . It is believed that the greater the case-resolving capacity of a service, the more oriented and prepared it is to cater to the users' health needs, even if this means referring them to another service to follow the treatment up ${ }^{10}$.

The case-resolving capacity in a model that is hierarchically structured by levels of attention can be assessed by two aspects: the first, within the service itself, according to its capacity to cater to demand and to refer those cases that require more specialized care, and the second, within the health system, which goes from the users' first appointment in the primary health care service to the solution of their problems at other levels of health care ${ }^{10}$. Although information systems can offer clinical and epidemiological data to subsidize the analysis and measure the case-resolving capacity of a service or health system, perhaps the most important information can only be obtained firsthand from the users themselves. Since the perception of an individual about a given service is very particular, it becomes difficult to identify what exactly a service that is able to solve his or her health problem means ${ }^{10}$, so it is fundamental to listen to him/ her.

No articles were found in the literature the outcome of which is the case-resolving capacity of dental care based on the users' perceptions. Therefore, and owing to the importance of the theme, this study sought to know what the views of users were on the case-resolving capacity of dental care in the SUS and to analyze the associations between solving capacity and both sociodemographic characteristics and access to the service.

\section{Methods}

\section{Study characterization}

This inquiry-type cross-sectional study with a quantitative approach was part of a multi-centric project that investigated various aspects of dental care offered by the SUS based on the point of view of users. The population of the study consisted of 461 users of the SUS oral health service in the municipality of Araçatuba, São Paulo, Brazil, aged $\geq 18$ years, who agreed to participate in the study, and who, on the day of the interview, were waiting for their consultation at the dental care health center they had appointed with. Persons aged $<18$ years who had cognitive special needs as well as those who were visiting the dental surgeon (DS) for the first time in the said health center were excluded from the study.

\section{Data collection}

Data collection was made through individual interviews conducted in a private environment in the sixteen urban zone health centers of the municipality that offered primary dental care. The recording of information was made on printed 
forms in which were the questions to be applied. The interviews occurred between November 2013 and May 2014, and were proportionally distributed among the health centers, according to demand. They were carried out in a standardized way by three DSs duly trained to gather the information without influencing the answers. Users were randomly selected, on alternate days and times of operation of health centers. The questionnaire was adapted based on the model used for the users satisfaction survey in the National Health Service Evaluation Program ${ }^{11}$ (Programa Nacional de Avaliação dos Serviços de Saúde - PNASS), and on the instruments of external evaluation of the Improvement Access and Quality National Program of Primary Health Care $^{12,13}$ (Programa de Melhoria do Acesso e da Qualidade - PMAQ). A pilot study was carried out beforehand to detect possible problems and to adjust the collecting instrument regarding the vocabulary used and the sensitivity of the questions. The data obtained during the pilot study were not part of the results of this research. At the end of each interview, users were given a printed manual elaborated for the research, with information about their rights and duties towards the SUS ${ }^{14}$; and, also, a kit containing a toothbrush, toothpaste and dental floss.

\section{Study variables}

The case-resolving capacity of the dental care service, as seen from the point of view of users, was the outcome variable of this study. To obtain it, the respondents answered the following question: "In your opinion, is the dentist of this center managing to solve all your oral health problems? (Yes/No)". The independent variables were divided into the following two groups: sociodemographic (sex; age range; occupation; marital status; educational level; family income; and type of health center where the user is attended to), and related to access to the service (reason why the service was sought; orientation to seek the service; distance from the user's home to the health center; satisfaction as to the way he/she is received; convenience of the DS's working hours; time to set an appointment; form of getting an appointment; waiting time in the waiting room; referral to a specialized treatment; success or failure to make an appointment with the specialist; time to schedule an appointment with the specialist). The respondents were also asked through an open question what had to be improved in the dental care of the health center. The categoriza- tion of the variables was made from those existing in PNASS ${ }^{11}$ and PMAQ ${ }^{12,13}$ instruments, with some adjustments.

\section{Sample calculation}

In the sample calculation, for an adult population estimated at 134,608 inhabitants, a prevalence of $50 \%$ was used for each possible answer (Yes/No) to the question containing the outcome variable, with the purpose of maximizing the size of the sample. Seeking to leverage the effect of the study, 20\% (77) were added to the total number found (384), thus reaching 461 individuals in the final sample. The level of confidence was stipulated at $95 \%$, and the maximum sample error at 5\%.

\section{Data analysis}

The data resulting from closed questions and their associations with the outcome variable were analyzed with the help of version 9.3 SAS statistical package ${ }^{15}$. Bivariable analyses were performed preliminarily by applying chi-square tests and Fisher's exact test, the latter being used when the former proved inadequate. Subsequently, the variables associated to the case-resolving capacity of dental care at a level of significance lower than $5 \%(\mathrm{p}<0.05)$ were included in a multivariable analysis. At this stage, the Poisson regression was used, with a level of significance of $5 \%$, and confidence intervals of 95\% (CI 95\%), so that the extent of the associations could be verified based on prevalence ratios (PR).

It was decided to use Poisson regression because it is a method for directly obtaining the PR, which is the appropriate measure of association for studies with cross-sectional design ${ }^{16}$, especially in cases where the outcome prevalence is greater than $10 \%{ }^{17}$. In this situation, the use of logistic regression could bring measures of association (odds ratios - OR) overestimated ${ }^{18}$. For the data originating from the open question, the answers were analyzed several times, and the converging contents were grouped into matrixes, which led to thematic categories ${ }^{19}$.

\section{Ethical considerations}

This study was approved by the Ethics in Research with Human Beings Committee of the Araçatuba School of Dentistry - Universidade Estadual Paulista Júlio de Mesquita Filho (UNESP). All the participants signed an Informed Consent Term, which included the objectives of the re- 
search, and information on voluntary participation, confidentiality, and possibility of dropping out.

\section{Results}

On being questioned about the case-resolving capacity of the dental care, $73.3 \%$ of the respondents said that they were having their oral health problems solved, $24.1 \%$, that they were not, and only $2.6 \%$ refused to give their opinion on the matter, the latter being discarded for the effect of result analysis. Some other questions also remained unanswered, thus leading to small differences in the absolute number of respondents.

Among the participants, the following prevailed: the female gender $(70.8 \%)$, employees $(44.5 \%)$, single persons $(57.9 \%)$, those within the 18-29-year age range (26.1\%), and those with a family income lower than two minimum salaries $(68.0 \%)$. As to educational level, $41.6 \%$ had only finished elementary school, and $48.5 \%$, high school. The majority $(81.7 \%)$ were attended to at one of the twelve health centers that integrated the ESF.

In observing the questions related to access to the service, it was found that only $16.3 \%$ of the individuals sought care as prevention, while 27.8 $\%$ did so for being in pain. The other variables of access showed that $61.5 \%$ of the respondents received no orientation to refer to a DS; $62.6 \%$ lived near the health center; $90.2 \%$ were satisfied with the way they were received; $92.2 \%$ found the DS's working hours good, and appropriate; $54.9 \%$ managed to set an appointment with no delay; $67.0 \%$ were seen through an appointed time; $52.9 \%$ waited for a short while in the waiting room; $27.4 \%$ had been referred to a specialist, and $25.8 \%$ out of these had not been able to set a specialized appointment.

Moreover, $45.5 \%$ of the respondents said that nothing had to be improved in the dental care of the health center. However, among the remaining $54.5 \%$, various suggestions were given, from improving the physical structure of the health center to acquiring dental materials of a higher quality. Among the most frequent thematic categories in the users' utterances, two stood out: a wish for better access to the service $(27.9 \%)$ and an increase in the number of DSs to attend to the population (15.8\%).

Tables 1 and 2 show the bivariable statisti$\mathrm{cal}$ analyses between the case-resolving capacity of dental care and the independent variables.
Among the sociodemographic characteristics (Table 1), only the type of health center where the user was attended to showed a significant association $(\mathrm{p}=0.019)$. Among the variables of access (Table 2), the reason why the service was sought $(\mathrm{p}=0.015)$; the distance between home and health center $(\mathrm{p}=0.011)$; the satisfaction concerning the way the user is received $(\mathrm{p}<0.001)$; the convenience of the DS's working hours ( $\mathrm{p}<0.001)$; the time required to set an appointment at the health center $(\mathrm{p}<0.001)$; and the time spent in the waiting room on the day of the appointment $(\mathrm{p}<0.001)$ were significantly associated to the case-resolving capacity of the service.

Table 3 shows the results of multivariable analysis, with adjusted prevalence ratios of the non-perception of the case-resolving capacity of dental care, according to the independent variables that had had a significant association in the bivariable analyses. The lack of case-resolving capacity was statistically associated to not considering the DS's working hours good and convenient $(\mathrm{RP}=2.65: \mathrm{CI} 95 \%: 1.63-4.31)$; to the long time it took to schedule an appointment in the health center ( $\mathrm{RP}=1.67$; CI 95\%: 1.03-2.73); and to the long time spent in the waiting room $(\mathrm{RP}=2.19$; CI 95\%: 1.23-3.91). The other variables did not remain significantly associated after the multivariable analysis.

\section{Discussion}

The aim of this study was to know what the views of users were about the case-resolving capacity of dental care at the SUS. The high case-resolving capacity that was found may have been a reflex of the smooth running of the visited health centers, by their putting into practice the precepts of the SUS and of PNSB, and by managing to cater to most of the population's oral health needs. However, this study was not developed based on numerical data taken from health information systems, or from oral health normative needs diagnosed in epidemiological exams. In seeking to know the case-resolving capacity of the service based on the users' responses, information was gathered at its source, yet it is important to think critically and to consider the subjectivity involved. Each individual has his or her own expectations regarding the service, and depending on what they are, the sensation of having his or her problems solved can be reached with more or less ease. The simple fact of having had access to 
Table 1 Bivariable analyses between the case-resolving capacity of dental care and sociodemographic characteristics. Araçatuba, São Paulo, 2013/2014.

\begin{tabular}{|c|c|c|c|c|c|c|c|}
\hline \multirow{3}{*}{ Variable } & \multicolumn{6}{|c|}{ Case-resolving capacity of the service } & \multirow{3}{*}{$\mathrm{p}$ value } \\
\hline & \multicolumn{2}{|c|}{ Yes } & \multicolumn{2}{|c|}{ No } & \multicolumn{2}{|c|}{ Total } & \\
\hline & $\mathbf{n}$ & $\%$ & $\mathbf{n}$ & $\%$ & $\mathbf{n}$ & $\%$ & \\
\hline \multicolumn{8}{|l|}{ Sex } \\
\hline Male & 96 & 73.3 & 35 & 26.7 & 131 & 100.0 & \multirow{2}{*}{0.529} \\
\hline Female & 242 & 76.1 & 76 & 23.9 & 318 & 100.0 & \\
\hline \multicolumn{8}{|l|}{ Age range } \\
\hline 18 to 29 & 84 & 71.8 & 33 & 28.2 & 117 & 100.0 & \multirow{5}{*}{0.291} \\
\hline 30 to 39 & 74 & 77.9 & 21 & 22.1 & 95 & 100.0 & \\
\hline 40 to 49 & 85 & 79.4 & 22 & 20.6 & 107 & 100.0 & \\
\hline 50 to 59 & 48 & 67.6 & 23 & 32.4 & 71 & 100.0 & \\
\hline 60 or more & 47 & 79.7 & 12 & 20.3 & 59 & 100.0 & \\
\hline \multicolumn{8}{|l|}{ Occupation } \\
\hline Employee & 160 & 80.0 & 40 & 20.0 & 200 & 100.0 & \multirow{6}{*}{0.321} \\
\hline Self-employed & 49 & 74.2 & 17 & 25.8 & 66 & 100.0 & \\
\hline Retired & 31 & 75.6 & 10 & 24.4 & 41 & 100.0 & \\
\hline Housewife & 59 & 70.2 & 25 & 29.8 & 84 & 100.0 & \\
\hline Student & 25 & 69.4 & 11 & 30.6 & 36 & 100.0 & \\
\hline Unemployed & 14 & 63.6 & 8 & 36.4 & 22 & 100.0 & \\
\hline \multicolumn{8}{|l|}{ Marital Status } \\
\hline Married/Consensual Union & 98 & 72.1 & 38 & 27.9 & 136 & 100.0 & \multirow{4}{*}{0.303} \\
\hline Single & 195 & 75.0 & 65 & 25.0 & 260 & 100.0 & \\
\hline Separated/Divorced & 16 & 88.9 & 2 & 11.1 & 18 & 100.0 & \\
\hline Widow/Widower & 29 & 82.9 & 6 & 17.1 & 35 & 100.0 & \\
\hline \multicolumn{8}{|l|}{ Educational level } \\
\hline Higher education & 27 & 61.4 & 17 & 38.6 & 44 & 100.0 & \multirow{3}{*}{0.058} \\
\hline High school & 170 & 78.3 & 47 & 21.7 & 217 & 100.0 & \\
\hline Elementary school & 140 & 75.3 & 46 & 24.7 & 186 & 100.0 & \\
\hline \multicolumn{8}{|l|}{ Family income } \\
\hline$<2$ minimum salaries & 220 & 74.3 & 76 & 25.7 & 296 & 100.0 & \multirow{2}{*}{0.550} \\
\hline$\geq 2$ minimum salaries & 107 & 77.0 & 32 & 23.0 & 139 & 100.0 & \\
\hline \multicolumn{8}{|l|}{ Type of health center } \\
\hline With ESF & 268 & 73.0 & 99 & 27.0 & 367 & 100.0 & \multirow{2}{*}{0.019} \\
\hline Without ESF & 70 & 85.4 & 12 & 14.6 & 82 & 100.0 & \\
\hline
\end{tabular}

The differences in the number of respondents between some variables correspond to unanswered questions.

the health service can lead to an overvaluation of the care received ${ }^{20}$.

Although some authors have published articles about case-resolving capacity in health, their investigations did not take place in oral health services $^{8,10,21,22}$, or they took into account means other than the perception of users/patients to verify solving capacity ${ }^{23}$. Moreover, other studies are related to the theme, yet only tangentially, since they offer other outcomes ${ }^{24,25}$. Therefore, the existing results that can be compared with those obtained in this study are rather scarce, es- 
Table 2 Bivariable analyses between the case-resolving capacity of dental care and variables related to access. Araçatuba, São Paulo, 2013/2014.

\begin{tabular}{|c|c|c|c|c|c|c|c|}
\hline \multirow{3}{*}{ Variable } & \multicolumn{6}{|c|}{ Case-resolving capacity of the service } & \multirow{3}{*}{ p value } \\
\hline & \multicolumn{2}{|c|}{ Yes } & \multicolumn{2}{|c|}{ No } & \multicolumn{2}{|c|}{ Total } & \\
\hline & $\mathbf{n}$ & $\%$ & $\mathbf{n}$ & $\%$ & n & $\%$ & \\
\hline \multicolumn{8}{|l|}{ Reason why service was sought } \\
\hline Reexamination/Prevention & 61 & 83.6 & 12 & 16.4 & 73 & 100.0 & \multirow{5}{*}{0.015} \\
\hline Pain & 84 & 67.2 & 41 & 32.8 & 125 & 100.0 & \\
\hline Extraction & 10 & 55.6 & 8 & 44.4 & 18 & 100.0 & \\
\hline Treatment & 180 & 78.6 & 49 & 21.4 & 229 & 100.0 & \\
\hline Other & 3 & 75.0 & 1 & 25.0 & 4 & 100.0 & \\
\hline \multicolumn{8}{|l|}{ Orientation to seek the service } \\
\hline No one & 205 & 74.3 & 71 & 25.7 & 276 & 100.0 & \multirow{5}{*}{0.209} \\
\hline Relative or friend & 86 & 78.2 & 24 & 21.8 & 110 & 100.0 & \\
\hline Community Health Agent & 15 & 75.0 & 5 & 25.0 & 20 & 100.0 & \\
\hline Other professionals of the health center & 21 & 65.6 & 11 & 34.4 & 32 & 100.0 & \\
\hline Other & 11 & 73.0 & 0 & 00.0 & 11 & 100.0 & \\
\hline \multicolumn{8}{|l|}{ Distance between home and health center } \\
\hline Near & 218 & 77.6 & 63 & 22.4 & 281 & 100.0 & \multirow{3}{*}{0.01} \\
\hline Reasonable & 80 & 78.4 & 22 & 21.6 & 102 & 100.0 & \\
\hline Far & 40 & 60.6 & 26 & 39.4 & 66 & 100.0 & \\
\hline \multicolumn{8}{|l|}{ Satisfaction as to the way you are received } \\
\hline Satisfied & 322 & 79.5 & 83 & 20.5 & 405 & 100.0 & \multirow{3}{*}{$<0.001$} \\
\hline More or less & 15 & 42.9 & 20 & 57.1 & 35 & 100.0 & \\
\hline Dissatisfied & 1 & 11.1 & 8 & 88.9 & 9 & 100.0 & \\
\hline \multicolumn{8}{|l|}{ Convenience of the DS's working hours } \\
\hline Yes & 330 & 79.9 & 83 & 20.1 & 413 & 100.0 & \multirow{2}{*}{$<0.00$} \\
\hline No & 8 & 22.9 & 27 & 77.1 & 35 & 100.0 & \\
\hline \multicolumn{8}{|l|}{ Time to set an appointment } \\
\hline Did not take long & 203 & 82.9 & 42 & 17.1 & 245 & 100.0 & \multirow{3}{*}{$<0.001$} \\
\hline Took a while & 84 & 73.0 & 31 & 27.0 & 115 & 100.0 & \\
\hline Took a long time & 48 & 55.8 & 38 & 44.2 & 86 & 100.0 & \\
\hline \multicolumn{8}{|l|}{ Form of getting an appointment } \\
\hline Setting a day and time & 236 & 78.4 & 65 & 21.6 & 301 & 100.0 & \multirow{4}{*}{0.153} \\
\hline By order of arrival & 80 & 70.2 & 34 & 29.8 & 114 & 100.0 & \\
\hline Fitting into a time slot & 14 & 63.6 & 8 & 36.4 & 22 & 100.0 & \\
\hline Other & 8 & 66.7 & 4 & 33.3 & 12 & 100.0 & \\
\hline \multicolumn{8}{|l|}{ Time waiting in the waiting room } \\
\hline Not long & 221 & 83.4 & 44 & 16.6 & 265 & 100.0 & \\
\hline A little long & 104 & 71.7 & 41 & 28.3 & 145 & 100.0 & $<0.001$ \\
\hline Very long & 12 & 31.6 & 26 & 68.4 & 38 & 100.0 & \\
\hline Referral to a specialized treatment & & & & & & & \\
\hline Yes & 85 & 69.7 & 37 & 30.3 & 122 & 100.0 & 0091 \\
\hline No & 250 & 77.4 & 73 & 22.6 & 323 & 100.0 & 0.091 \\
\hline Success in scheduling an appointment with a s & & & & & & & \\
\hline Yes & 63 & 70.8 & 26 & 29.2 & 89 & 100.0 & 0750 \\
\hline No & 21 & 67.7 & 10 & 32.3 & 31 & 100.0 & 0.150 \\
\hline Time to schedule an appointment with the spe & & & & & & & \\
\hline Up to 1 week & 29 & 76.3 & 9 & 23.7 & 38 & 100.0 & \\
\hline From 1 week to 1 month & 19 & 67.9 & 9 & 32.1 & 28 & 100.0 & 0.599 \\
\hline More than 1 month & 15 & 65.2 & 8 & 34.8 & 23 & 100.0 & \\
\hline
\end{tabular}

The differences in the number of respondents between some variables correspond to unanswered questions. 
Table 3. Multivariable analysis between the non-case-resolving capacity of dental care and independent variables. Araçatuba, São Paulo, 2013/2014.

\begin{tabular}{|c|c|c|c|c|c|}
\hline \multirow[t]{2}{*}{ Variable } & \multicolumn{2}{|c|}{$\begin{array}{c}\text { Non-case-resolving } \\
\text { service }\end{array}$} & \multirow[t]{2}{*}{ Adjusted PR } & \multirow[t]{2}{*}{ (CI 95\%) } & \multirow[t]{2}{*}{ p value } \\
\hline & $\mathbf{n}$ & $\%$ & & & \\
\hline \multicolumn{6}{|c|}{ Convenience of the DS's working hour } \\
\hline Yes & 83 & 20.1 & 1.00 & & \\
\hline No & 27 & 77.1 & 2.65 & $1.63-4.31$ & $<0.001$ \\
\hline \multicolumn{6}{|l|}{ Time to set an appointment } \\
\hline Did not take long & 42 & 17.1 & 1.00 & & \\
\hline Took a while & 31 & 27.0 & 1.19 & $0.73-1.94$ & 0.473 \\
\hline Took a long time & 38 & 44.2 & 1.67 & $1.03-2.73$ & 0.037 \\
\hline \multicolumn{6}{|c|}{ Time waiting in the waiting room } \\
\hline Not long & 44 & 16.6 & 1.00 & & \\
\hline A little long & 41 & 28.3 & 0.66 & $0.42-1.02$ & 0.064 \\
\hline Very long & 26 & 68.4 & 2.19 & $1.23-3.91$ & 0.007 \\
\hline
\end{tabular}

The differences in the number of respondents between some variables correspond to unanswered questions.

pecially, when it comes to analyzing associations with independent variables.

Despite their different methods and scenarios, the majority of the articles found showed a case-resolving capacity that was similar to the present study. The results that were closest were those of Moimaz et al. ${ }^{24}(72.1 \%)$ and Santiago at al..$^{25}(78.6 \%)$. Silva et al..$^{22}$ obtained a little higher percentage $(86.6 \%)$, whereas Rosa et al. ${ }^{8}$ recorded an opposite situation (61.3\%).

In the bivariable analysis, the statistically significant association between case-resolving capacity and the type of health center where participants were attended to calls special attention when the frequencies described are observed. Contrary to what is expected, the percentage of users that declared that their oral health problems were being solved was greater among those that were seen at health centers without ESF, than among those seen at health centers with established ESF. This finding may be related to the fact that the DSs and assistants of the four health centers without ESF that were visited belonged to the permanent staff of municipal servants, and had been working at these centers for years. According to Moraes et al. ${ }^{26}$, a follow-up over time offers users more adequate care. In contrast, in centers without ESF, it was observed during visits that most professionals had temporary employment contracts, mainly the DSs, thus leading to a higher degree of staff turnover. This, in turn, hampered the establishment of a longer and stronger relationship with users, and may have interfered in the perception of the case-resolving capacity offered by the service.

In observing two health centers, Finkler et al. ${ }^{21}$ also found a better case-resolving capacity in that which did not have ESF. To them, because of the use of "forms" and "evaluations", the center with ESF ended up drawing away from the principles that characterize family health as the strategy of preference to promote health to the population ${ }^{21}$. Conversely, in the study by Bulgareli et al. ${ }^{23}$, a statistically significant difference of $40.97 \%$ was found for the case-resolving capacity of centers without ESF, as compared to $83.56 \%$ of those with ESF.

Still in the bivariable analyses, a number of considerations can be drawn based on the significant associations obtained. The users who sought the service owing to pain or to have a tooth extraction regarded it as much less case-resolving than those who went to the center for a preventive treatment. Since less complex dental problems - identified very often in preventive appointments - tend to be easier to solve when compared with other more complex problems, this may have influenced the perception of the participants about the case-resolving capacity of the service, or about case-resolving capacity in general. Preventive care is one way of reducing the risk of diseases and improving the epidemiological profile of the population, preventing the gradual increase of the cost of dental treatment over time, as demonstrated by Warren et al. ${ }^{27}$. As an example of applying this approach, one 
can cite the free dental check-ups supply policy by the Scottish government, with the intention of improving the oral health of its citizens ${ }^{28}$. In general, the reason why the treatment is sought seems to be a factor that can interfere in patients' judgments. In a study conducted in London, the users whose last visit to the dentist had been because of problems with teeth were $10 \%$ less likely to be satisfied with the care received, when compared with those who had scheduled an appointment just for a check-up ${ }^{29}$.

Not living far and feeling totally satisfied with the way they are received at the health center were conditions that made a high percentage of individuals indicate that this was a case-resolving service. This is consistent with the points recommended by the Basic Care National Policy, which advocates that health centers be established close to where people live, since they play a critical role in the access of the population to health care ${ }^{30}$; and by the National Humanization Policy of Care and Management in the SUS, one of the guidelines of which is to welcome users and to make the entire team accountable for them, as a tool for good case-resolving capacity ${ }^{31}$.

Once the high rate of case-resolving capacity in the responses of the respondents was verified, the multivariable analysis was directed to the investigation of associations between the independent variables and the non-perception of case-resolving capacity, aiming to know what factors made the difference at the moment of this negative response. It was found that out of the three conditions (all of access) that were associated to a lack of case-resolving capacity, not considering the DS's working hours convenient was that which showed the strongest association. Difficulties of access related to the time of the appointment were reported in studies on oral health ${ }^{29}$ and health in general ${ }^{32}$. Users very often require a greater flexibility in service functioning hours ${ }^{29}$, mainly so that they may conciliate the appointments with their daily work routine $\mathrm{e}^{32}$.

In addition to the question of the appointment time, the excessive delay to get an appointment scheduled at the health center, and to be seen on the day of the appointment (staying a long time waiting in the waiting room) proved to be important to understand the accounts of lack of case-resolving capacity. Such difficulties were also felt in the United States, where in 2009, $24.7 \%$ of the patients of Federal Health Centers referred to having experienced a long delay in the access to the dental care they required ${ }^{33}$. The delay to schedule appointments not only discredits the solving capacity of public health services, but it also causes some persons to seek the private sector $^{34}$. This statement helps understand how it was that Brazil, with so many established ESBs, had only $19.6 \%$ of dental care in 2013 carried out at primary health care centers ${ }^{7}$.

In this study, the idea that the service had good case-resolving capacity was reinforced when almost half of the participants said that nothing had to be improved in the service. In contrast, the suggestions of the other respondents pointed to another direction. In their answers, some of the most present thematic categories, such as improving the access to dental care and increasing the number of DSs, remit to possible difficulty in obtaining access and to the existence of a repressed demand that need to solve their oral health problems. Al-Haboubi et al. ${ }^{29}$ reported on a similar situation in their research, in which $32 \%$ of users requested greater availability of DSs in the public health system, and $16 \%$ wished for better access to dental care.

The subjectivity that pertains to the object of this study and the possibly excessive value attributed to the phase of access to dental care on the part of users may have had an important role on the findings discussed here, and thus may have influenced our having obtained a high rate of assessed case-resolving capacity. Other studies on the theme in question are extremely important so that a stronger scientific framework regarding the investigated outcome may be built. Uniting academic knowledge to the experiences felt by users and health professionals alike can be a good path to understand case-resolving capacity and other matters present in oral health care.

\section{Conclusion}

This study showed the positive perception that users had regarding the case-resolving capacity of public dental care, and the existent relationship between access to the service and the said case-resolving capacity. Moreover, it was also concluded that sociodemographic conditions played a less significant role in this study of case-resolving capacity, when compared to variables of access. 


\section{Collaborations}

AMC Lima participated in data collection, and in the elaboration of the paper. SAS Moimaz participated in the conception and design of the study, in data analysis, and in the elaboration of the paper. CAS Garbin and NA Saliba participated in the conception and design of the study, and in the analysis of results. JE Corrente worked on data analysis. In addition, all the authors participated in data interpretation, in the critical review of the intellectual content, and in the approval of the final version to be published.

\section{Acknowledgements}

To the Brazilian National Council for Scientific and Technological Development (CNPq) for the financial assistance for this study.

\section{References}

1. Brasil. Instituto Brasileiro de Geografia e Estatística (IBGE). Censo Demográfico 2010. Rio de Janeiro: IBGE; 2010.

2. Brasil. Resolução no 1 , de 15 de janeiro de 2013. Diário Oficial da União 2013; 23 jan.

3. Paim J, Travassos C, Almeida C, Bahia L, Macinko J. The Brazilian health system: history, advances, and challenges. Lancet 2011; 377(9779):1778-1797.

4. Pucca Jr GA, Costa JFR, Chagas LD, Silvestre RM. Oral health policies in Brazil. Braz Oral Res 2009; 23(Spec Issue 1):9-16.

5. Brasil. Ministério da Saúde (MS). Secretaria de Atenção à Saúde. Departamento de Atenção Básica. Histórico de cobertura da Saúde da Família. [acessado 2016 Jan 22]. Disponível em: http://dab.saude.gov.br/portaldab/historico_cobertura_sf.php.

6. Brasil. Ministério da Saúde (MS). Secretaria de Atenção à Saúde. Departamento de Atenção Básica. Cidades Atendidas com Centros de Especialidades Odontológicas. [acessado 2016 Jan 22]. Disponível em: http://dab.saude.gov.br/portaldab/ape_brasil_sorridente.php?conteudo $=$ cidades_bs.

7. Brasil. Instituto Brasileiro de Geografia e Estatística (IBGE). Pesquisa Nacional de Saúde 2013: acesso e utilização dos serviços de saúde, acidentes e violências. Rio de Janeiro: IBGE; 2015.

8. Rosa RB, Pelegrini AHW, Lima MADS. Resolutividade da assistência e satisfação de usuários da Estratégia Saúde da Família. Rev Gaucha Enferm 2011; 32(2):345351.

9. Garbin AJI, Garbin CAS, Santos RR, Fagundes ACG, Marques JAM, Santos JG. Percepção do usuário em relação ao serviço odontológico público no Noroeste paulista. Rev Adm Saude 2011; 13(51):117-123.

10. Turrini RNT, Lebrão ML, Cesar CLG. Resolutividade dos serviços de saúde por inquérito domiciliar: percepção do usuário. Cad Saude Publica 2008; 24(3):663-674.

11. Brasil. Ministério da Saúde (MS). Secretaria de Atenção à Saúde. Departamento de Regulação Avaliação e Controle de Sistemas. Coordenação Geral de Regulação e Avaliação. Caderno do Programa Nacional de Avaliação dos Serviços de Saúde - PNASS: edição 2004-2005. Brasília: MS; 2004.

12. Brasil. Ministério da Saúde (MS). Secretaria de Atenção à Saúde. Departamento de Atenção Básica. Programa de Melhoria do Acesso e da Qualidade - PMAQ: instrumento de avaliação externa para as equipes de atenção básica. Brasília: MS; 2013.

13. Brasil. Ministério da Saúde (MS). Secretaria de Atenção à Saúde. Departamento de Atenção Básica. Programa de Melhoria do Acesso e da Qualidade - PMAQ: instrumento de avaliação externa para as equipes de saúde bucal. Brasília: MS; 2013.

14. Moimaz SAS, Fadel CB, Bordin D, Rovida TAS, Saliba NA. Cidadania e saúde bucal. Araçatuba: FOA/UNESP; UEPG; 2013.

15. SAS Institute Inc. SAS System for Windows. [computer program]. Version 9.3. Cary: SAS Institute Inc.; 2011.

16. Fletcher RH, Fletcher SW. Epidemiologia clínica: elementos essenciais. $4^{a}$ ed. Porto Alegre: ARTMED; 2006. 
17. Behrens T, Taeger D, Wellmann J, Keil U. Different methods to calculate effect estimates in cross-sectional studies: a comparison between prevalence odds ratio and prevalence ratio. Methods Inf Med 2004; 43(5):505509.

18. Thompson ML, Myers JE, Kriebel D. Prevalence odds ratio or prevalence ratio in the analysis of cross sectional data: what is to be done? Occup Environ Med 1998; 55(4):272-277.

19. Bardin L. Análise de conteúdo. $3^{\mathrm{a}}$ ed. Lisboa: Edições 70; 2004.

20. Serapioni M, Silva MGC. Avaliação da qualidade do Programa Saúde da Família em municípios do Ceará. Uma abordagem multidimensional. Cienc Saude Coletiva 2011; 16(11):4315-4326.

21. Finkler AL, Viera CS, Tacla MTGM, Toso BRGO. The access and the difficulty in resoluteness of the child care in primary health care. Acta Paul Enferm 2014; 27(6):548-553.

22. Silva MA, Santos MLM, Bonilha LAS. Users' perceptions of outpatient physiotherapy in the public healthcare system in Campo Grande (MS, Brazil): problem-solving capacity and difficulties. Interface (Botucatu) 2014; 18(48):75-86.

23. Bulgareli J, Cortellazzi KL, Ambrosano GMB, Meneghim MC, Faria ET, Mialhe FL, Pereira AC. A resolutividade em saúde bucal na atenção básica como instrumento para avaliação dos modelos de atenção. Cien Saude Coletiva 2014; 19(2):383-391.

24. Moimaz SAS, Marques JAM, Saliba O, Garbin CAS, Zina LG, Saliba NA. Satisfação e percepção do usuário do SUS sobre o serviço público de saúde. Physis 2010; 20(4):1419-1440.

25. Santiago RF, Mendes ACG, Miranda GMD, Duarte PO, Furtado BMASM, Souza WV. Qualidade do atendimento nas Unidades de Saúde da Família no município de Recife: a percepção do usuário. Cien Saude Coletiva 2013; 18(1):35-44.

26. Moraes VD, Campos CEA, Brandão AL. Estudo sobre dimensões da avaliação da Estratégia Saúde da Família pela perspectiva do usuário. Physis 2014; 24(1):127146.

27. Warren E, Pollicino B, Curtis B, Evans W, Sbaraini A, Schwarz E. Modeling the long-term cost-effectiveness of the Caries Management System in an Australian population. Value Health 2010; 13(6):750-760.

28. Ikenwilo D. A difference-in-differences analysis of the effect of free dental check-ups in Scotland. Soc Sci Med 2013; 83:10-18.
29. Al-Haboubi M, Klass C, Jones K, Bernabé E, Gallagher JE. Inequalities in the use of dental services among adults in inner South East London. Eur J Oral Sci 2013; 121(3):176-181.

30. Brasil. Ministério da Saúde (MS). Secretaria de Atenção à Saúde. Departamento de Atenção Básica. Política $\mathrm{Na}$ cional de Atenção Básica. Brasília: MS; 2012.

31. Brasil. Ministério da Saúde (MS). Secretaria de Atenção à Saúde. Núcleo Técnico da Política Nacional de Humanização. HumanizaSUS: documento base para gestores e trabalhadores do SUS. $4^{\mathrm{a}}$ ed. $5^{\mathrm{a}}$ reimp. Brasília: MS; 2012.

32. Schmied V, Homer C, Fowler C, Psaila K, Barclay L, Wilson I, Kemp L, Fasher M, Kruske S. Implementing a national approach to universal child and family health services in Australia: professionals' views of the challenges and opportunities. Health Soc Care Community 2015; 23(2):159-170.

33. Jones E, Shi L, Hayashi AS, Sharma R, Daly C, NgoMetzger Q. Access to oral health care: the role of Federally Qualified Health Centers in addressing disparities and expanding access. Am J Public Health 2013; 103(3):488-493.

34. Santos TVC, Penna CMM. Demandas cotidianas na atenção primária: o olhar de profissionais de saúde e usuários. Texto Contexto Enferm 2013; 22(1):149-156.

Artigo apresentado em 27/01/2016

Aprovado em 21/08/2016

Versão final apresentada em 23/08/2016 